\title{
Uji in Vitro Senyawa Antikanker SA 2014 terhadap Aktivitas Fagositosis Sel Makrofag (Mus musculus)
}

\author{
Akhlaqul Karimaa \\ Departemen Biologi, Fakultas Ilmu Alam, Institut Teknologi Sepuluh Nopember (ITS) \\ e-mail:kakhlaqul26@gmail.com
}

\begin{abstract}
Abstrak-Kanker merupakan kelainan dengan karakteristik mutasi yang mengganggu mekanisme kontrol normal dan berpotensi menghasilkan sel-sel yang berbahaya. Pengobatan yang diterapkan di Indonesia masih belum mendapatkan hasil yang memuaskan serta menimbulkan efek samping. Senyawa SA 2014 yang diisolasi dari spons laut Cinachyrella anomala dapat berperan sebagai imunomodulator dan berpotensi menjadi alternatif pengobatan kanker. Penelitian ini dilakukan untuk mengetahui konsentrasi senyawa SA 2014 yang paling optimal dalam meningkatkan aktivitas fagositosis sel makrofag. Uji aktivitas fagositosis dilakukan secara in vitro dengan menambahkan senyawa SA 2014 dan doxorubicin sebagai pembanding dengan konsentrasi $10 \mu \mathrm{g} / \mathrm{mL}, 5 \mu \mathrm{g} / \mathrm{mL}$, $2,5 \mu \mathrm{g} / \mathrm{mL}, \quad 1,25 \mu \mathrm{g} / \mathrm{mL}$ serta $0 \mu \mathrm{g} / \mathrm{mL}$ (kontrol) pada sel makrofag mencit, selanjutnya ditambahkan latex beads. Aktivitas fagositosis dinyatakan dalam kapasitas fagositosis dan indeks fagositosis. Hasil penelitian ini yakni senyawa SA 2014 dapat meningkatkan aktivitas fagostosis pada konsentrasi $2,5 \mu \mathrm{g} / \mathrm{mL}$ dengan kapasitas fagositosis serta indeks fagositosis 2 kali lebih besar dibanding kontrol, sedangkan perlakuan doxorubicin dapat meningkatkan kapasitas fagositosis pada konsentrasi $5 \mu \mathrm{g} / \mathrm{mL} 1,06$ kali lebih besar dibanding kontrol namun tidak dapat meningkatkan indeks fagositosis.
\end{abstract}

Kata kunci-Fagositosis, Imunomodulator, Makrofag dan SA 2014.

\section{PENDAHULUAN}

K ANKER merupakan kelainan yang dikarakterisasikan dengan mutasi yang mengganggu mekanisme control normal dan berpotensi menghasilkan sel-sel yang berbahaya [1]. Organisasi Kesehatan Dunia (WHO) mengestimasikan bahwa 84 juta orang meninggal akibat kanker dalam rentang waktu 2005-2015 [2]. Salah satu karakteristik kanker adalah terjadinya penghambatan proses apoptosis yang berhubungan dengan resistensi sel kanker terhadap kemoterapi maupun radioterapi. Kemoterapi merupakan penggunaan obat yang menghentikan replikasi dan pembelahan sel dalam pengobatan kanker [3] sedangkan radioterapi adalah pengobatan kanker menggunakan radiasi partikel atau gelombang berenergi tinggi seperti sinar-X, gamma, elektron atau proton untuk menghancurkan atau merusak sel kanker [4]. Selain kedua metode tersebut, pembedahan merupakan metode pengobatan kanker yang

banyak diterapkan di Indonesia. Prinsip dasar metode ini adalah pengambilan sel kanker secara langsung melalui pembedahan [5].

Beberapa jenis terapi yang telah disebutkan sebelumnya belum mendapatkan hasil yang memuaskan serta menimbulkan efek samping, sehingga perlu dicari alternatif lain dalam usaha pengobatan penyakit tersebut salah satunya dengan penggunaan bahan-bahan yang bersifat imunomodulator dalam terapi kanker. Senyawa imunomodulator merupakan senyawa yang dapat menginduksi peningkatan aktivitas sistem imun di dalam tubuh. Senyawa tersebut dapat memicu proses apoptosis secara alami [6]. Apoptosis adalah kematian sel terprogram (programed cell death) yang bertujuan untuk mempertahankan kestabilan populasi sel. Peningkatan apoptosis merupakan suatu upaya yang dikembangkan sebagai terapi kanker saat ini [7].

Senyawa SA 2014 merupakan salah satu senyawa yang bersifat imunomodulator. Senyawa ini diisolasi dari spons laut $C$. anomala dan termasuk dalam kelompok alkaloid [8]. Senyawa alkaloid ini berperan dalam menghambat proliferasi dan induksi siklus sel pada fase sub- $G_{1}$ dan fase $\mathrm{G}_{2} / \mathrm{M}$ serta sebagai inhibitor $\mathrm{CDK} 2$ yang menghambat progres siklus sel pada fase $G_{1}$ menuju ke fase $S$ [9]. Senyawa SA 2014 secara tidak langsung dapat meningkatkan fagositosis makrofag. Fagositosis merupakan mekanisme pertahanan tubuh terhadap serangan mikroorganisme yang juga berperan dalam mengeliminasi sel-sel yang telah rusak [10]. Sel-sel yang telah mengalami apoptosis akan dieliminasi dalam proses fagositosis oleh makrofag yang mengenali sinyal spesifik yang ditunjukkan oleh sel yang mengalami apoptosis [11]. Oleh karena itu penelitian mengenai efektivitas senyawa SA 2014 dalam meningkatkan aktivitas fagositosis harus dilakukan untuk mengetahui potensinya sebagai bahan obat kanker mengingat pengobatan yang yang diterapkan saat ini belum mendapatkan hasil yang memuaskan serta menimbulkan efek samping.

\section{METODE PENELITIAN}

Penelitian ini dilakukan pada Juni 2017-Mei 2018 di Laboraturium Parasitologi, Fakultas Kedokteran Universitas Gadjah Mada Yogyakarta. Selanjutnya perhitungan dan analisis data dilakukan di Laboratorium Zoologi dan Rekayasa Hewan, Departemen Biologi Fakultas Ilmu Alam Institut Teknologi Sepuluh Nopember, Surabaya

\section{A. Aklimatisasi Mencit}

Mencit (Mus musculus) jantan galur Swiss webster sejumlah 3 ekor berumur 8-10 minggu dengan berat badan 20-30 g diaklimatisasi selama 1 minggu di tempat pemeliharaan mencit (animal house). Mencit diberi makan pellet standar dan air ad libitum [12]. 


\section{B. Preparasi Sampel Uji}

Senyawa SA 2014 didapatkan dari hasil penelitian sebelumnya berupa larutan dengan konsentrasi senyawa 200 ppm sebanyak $200 \mu$ l [7]. Stok larutan SA 2014 yang didapatkan selanjutnya diencerkan secara bertingkat dengan menambahkan $200 \mu \mathrm{l}$ SA 2014 ke dalam 3,8 ml RPMI dingin, kemudian dihomogenkan. Selanjutnya diambil $2 \mathrm{ml}$ larutan dari tabung tersebut dan dimasukkan ke dalam tabung reaksi kedua yang berisi $2 \mathrm{ml}$ RPMI dingin. Langkah ini diulang hingga tabung reaksi keempat sehingga didapatkan suspensi larutan SA 2014 pada tabung reaksi 1-4 dengan konsentrasi secara berturut-turut $10 \mu \mathrm{g} / \mathrm{mL} ; 5 \mu \mathrm{g} / \mathrm{mL} ; 2,5 \mu \mathrm{g} / \mathrm{mL} ; 1,25 \mu \mathrm{g} / \mathrm{mL}$ [12].

\section{Isolasi dan Kultur Sel Makrofag}

Mencit yang telah diaklimatisasi dibius menggunakan kloroform (bius hirup). Mencit diletakkan di papan bedah dalam posisi terlentang. Kulit bagian perut dibersihkan dengan alkohol $70 \%$ kemudian dibuka menggunakan dissection set. Selanjutnya $10 \mathrm{ml}$ RPMI 1640 dingin disuntikkan ke rongga peritoneum dan ditunggu sekitar 3 menit sambil rongga peritoneumnya ditekan secara perlahan [12].

Cairan peritoneum selanjutnya diaspirasi menggunakan jarum suntik, kemudian disentrifus pada $5000 \mathrm{rpm} 4^{\circ} \mathrm{C}$ selama 3 menit. Setelah disentrifus bagian supernatan dibuang, sedangkan bagian pelet disuspensikan pada media RPMI lengkap (medium RPMI yang ditambah dengan Fetal Bovine Serum (FBS) 10\%, amfoterisin B $0,5 \%$ dan penisilin/streptomisin $1 \%$ ) hingga $15 \mathrm{ml}$. Pellet yang telah disuspensikan pada RPMI lengkap divortex dengan kecepatan $1800 \mathrm{rpm}$ selama 10 detik. Suspensi pellet kemudian diambil beberapa tetes dan dihitung jumlah selnya dengan hemositometer. Setelah jumlah sel didapatkan, suspensi diencerkan dengan RPMI lengkap hingga didapat kepadatan sel 2,5 x 106/ml [12].

Suspensi yang didapatkan selanjutnya diambil sebanyak $200 \mu \mathrm{l}\left(5 \times 10^{5} \mathrm{sel}\right)$ dan dimasukkan dalam sumuran yang telah dilapisi cover slips. Sel-sel makrofag tersebut dikulturkan pada inkubator $\mathrm{CO}_{2} 5 \%$, suhu $37^{\circ} \mathrm{C}$ selama 30 menit. Inkubasi dilanjutkan hingga 24 jam setelah sebelumnya masing-masing sumuran ditambah RPMI lengkap sebanyak $300 \mu 1$ [12].

\section{Uji Fagositosis dengan Latex Beads}

Uji kemampuan fagositosis non-spesifik dilakukan secara in vitro menggunakan latex beads. Medium pada sumuran yang telah berisi kultur sel makrofag dibuang terlebih dahulu kemudian dicuci dengan RPMI sebanyak 2

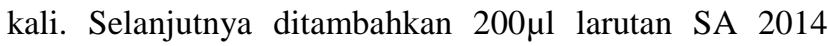
dengan konsentrasi $10 \mu 1 ; 5 \mu 1 ; 2,5 \mu 1 ; 1,25 \mu 1$ serta $0 \mu 1$ dengan 3 kali pengulangan pada masing-masing konsentrasi senyawa. Campuran tersebut didiamkan selama 4 jam. Setelah didiamkan, suspensi senyawa dibuang dan pada masing-masing sumuran ditambahkan latex beads sebanyak $200 \mu$ l. Sumuran tersebut selanjutnya diinkubasi selama 60 menit kemudian suspensi latex beads dibuang [12].

Sumuran selanjutnya dicuci dengan Phospat Buffered Saline (PBS), difiksasi dengan metanol dan dikeringkan dengan cara diangin-anginkan pada suhu kamar. Tahapan selanjutnya adalah pewarnaan dengan Giemsa $10 \%$ kemudian dicuci dan dikeringkan. Setelah dicuci dan dikeringkan, cover slips diambil dari dalam sumuran dan diamati di bawah mikroskop dengan perbesaran 400 kali. Pada pengamatan mikroskop dihitung jumlah latex beads yang difagositosis dan makrofag yang aktif memfagosit tiap 300 sel makrofag [12]. Data yang didapatkan digunakan untuk menghitung kapasitas fagositosis dan indeks fagositosis dengan persamaan berikut [13]:

Kapasitas fagositosis $=$ jumlah sel makrofag aktif $\quad \mathrm{x} 100 \%$ jumlah sel makrofag total (300)

Indeks fagositosis $=$ jumlah latex beads yang terfagositosis jumlah sel makrofag aktif

Data yang diperoleh dari kapasitas dan indeks fagositosis makrofag diuji dengan menggunakan One Way ANOVA untuk mengetahui pengaruh pemberian SA 2014 terhadap fagositosis makrofag dengan taraf kepercayaan 95\% kemudian dilanjutkan dengan uji Tukey untuk mengetahui konsentrasi yang paling optimal dalam meningkatkan aktivitas fagositosis [12].

\section{HASIL DAN PEMBAHASAN}

Pada penelitian ini digunakan sel makrofag sebagai sel uji karena kemampuan sel makrofag yang dapat menempel pada coverslips membedakannya dengan sel-sel lainnya [14]. Sel makrofag yang digunakan diisolasi dari peritoneum mencit. Rongga peritoneum merupakan tempat yang mudah untuk memanen Resident Peritoneal Makrofag (RPM) yang merupakan sel fagosit yang hidup bebas pada rongga peritoneal. Jutaan resident makrofag dapat diambil dari rongga peritoneum satu mencit. Oleh sebab itu sel makrofag dari rongga peritoneum banyak digunakan dalam penelitian-penelitian yang berhubungan dengan imunologi [15].

Medium yang digunakan dalam proses isolasi serta kultur sel makrofag adalah Roswell Park Memorial Institute 1640 (RPMI 1640). Medium RPMI mengandung glukosa, vitamin, phenol red sebagai indikator $\mathrm{pH}$ (medium akan berubah warna saat $\mathrm{pH}$ berubah atau terjadi kontaminasi), garam mineral $\left(\mathrm{NaCl}, \mathrm{NaCO}_{3}, \mathrm{Na}_{2} \mathrm{PO}_{4}, \mathrm{CaNO}_{3}, \mathrm{MgSO}_{4}\right.$ dan $\mathrm{KCl}$ ) dan asam amino (glutamin, arginin, leusin, lisin dan serin) [16]. Medium tersebut dapat meningkatkan migrasi monosit ke dalam rongga peritoneum serta menjaga makrofag yang dikultur tetap hidup [14].

Makrofag yang dikultur dalam medium ditambahkan latex beads. Latex beads merupakan partikel asing yang sangat direspon baik oleh sistem imun mencit maupun manusia sehingga dapat menstimulus aktivitas fagositosis. Karakter latex beads adalah tidak dapat diwarnai sehingga pada saat proses pewarnaan dengan Giemsa akan didapatkan makrofag tampak berwarna keunguan sedangkan lateks tidak berwarna. Hasil pewarnaan tesebut dapat digunakan untuk membedakan antara lateks yang terfagositosis dan yang tidak terfagositosis. Kultur yang telah diwarnai selanjutnya dicuci dengan PBS untuk menghilangkan lateks yang tidak terfagositosis serta ditambahkan metanol untuk proses fiksasi [14]. Aktivitas fagositosis sel makrofag 
dapat diketahui dari pengamatan preparat yang tercetak pada cover slips dengan bantuan mikroskop.

\section{E. Morfologi Sel Makrofag Mencit (M. musculus) dengan Perlakuan Senyawa SA 2014 dan Doxorubicin}

Morfologi sel makrofag mencit (M. musculus) pada kelompok kontrol serta kelompok perlakuan senyawa SA 2014 dan doxorubicin menunjukkan perbedaan pada nukleus dan sitoplasma (Gambar 1). Morfologi sel makrofag kelompok kontrol maupun kelompok perlakuan SA 2014 menunjukkan adanya persamaan, yakni karakteristik sel makrofag yang normal. Sel makrofag normal (Gambar 1.A, $\mathrm{B}$ dan C) memiliki inti yang berbentuk bulat atau lonjong serta berwarna lebih gelap dibanding sitoplasma saat diberi

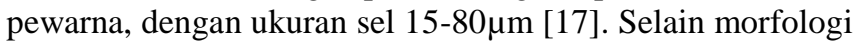
yang sama, sel makrofag kelompok kontrol dan kelompok perlakuan SA 2014 menunjukkan adanya pseudopodia (Gambar 1.B). Pseudopodia pada sel makrofag merupakan salah satu bentuk perubahan morfologi yang terjadi akibat adanya aktivasi makrofag oleh mikroorganisme patogen atau antigen yang lain Perlakuan SA 2014 tidak memberikan efek merusak pada sel makrofag karena morfologi sel yang normal dan adanya pseudopodia [18].
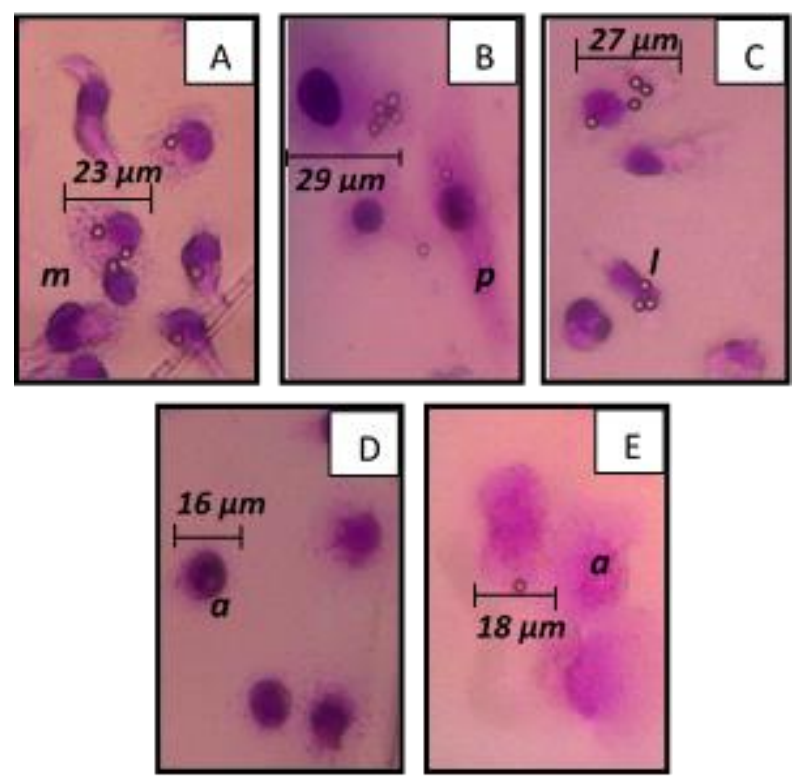

Gambar 1. Morfologi Sel Makrofag yang Diberi Perlakuan Senyawa SA 2014 dan Doxorubicin : (A) Kontrol, (B) SA 2014 Konsentrasi 2,5 $\mu \mathrm{g} / \mathrm{mL}$, (C) SA 2014 Konsentrasi $5 \mu \mathrm{g} / \mathrm{mL}$, (D) Doxorubicin Konsentrasi 2,5 $\mu \mathrm{g} / \mathrm{mL}$ dan (E) Doxorubicin Konsentrasi $5 \mu \mathrm{g} / \mathrm{mL}$ (Pengamatan Mikroskop Perbesaran 400x)

Keterangan : (m) makrofag, (l) latex beads, (p) peudopodia , (a) ap

Sel makrofag yang diberi perlakuan senyawa doxorubicin (Gambar 1. D dan E) menunjukkan adanya perubahan morfologi sel makrofag yakni apoptosis sel. Sel makrofag dengan perlakuan doxorubicin dengan konsentrasi $2,5 \mu \mathrm{g} / \mathrm{mL}$ (Gambar 1.D) mengalami apoptosis karena menunjukkan karakteristik apoptosis yakni volume sel berkurang, organel di sitoplasma terkondensasi namun membran sel relatif utuh, sedangkan sel makrofag dengan perlakuan doxorubicin dengan konsentrasi $5 \mu \mathrm{g} / \mathrm{mL}$ (Gambar 1.E) menunjukkan karakter apoptosis yakni fragmentasi nukleus yang diikuti sitoplasma dan membran sel [19].

Apoptosis yang terjadi pada sel makrofag dengan perlakuan doxorubicin diduga disebabkan oleh sifat sitotoksisitas doxorubicin. Doxorubicin memiliki kemampuan untuk merusak sel melalui menghasilkan radikal bebas dan menginduksi peroksidasi lipid. Selain itu doxorubicin dapat menghambat enzim-enzim esensial dalam replikasi seperti helikase dan topoisomerase II yang berperan dalam melepaskan untaian DNA sehingga proses replikasi DNA terhambat dan tidak dapat terjadi biosisntesis makromolekul yang menyebabkan kematian sel [20].

F. Kapasitas Fagositosis Sel Makrofag Mencit (M. musculus) dengan Perlakuan Senyawa SA 2014 dan Doxorubicin

Data yang didapatkan melalui pengamatan mikroskop digunakan dalam perhitungan kapasitas fagositosis untuk mengetahui nilai aktivitas makrofag (Tabel 1 dan Gambar 2). Kapasitas fagositosis merupakan persentase makrofag yang memfagositosis latex beads dari 300 makrofag [20].

Tabel 1.

Nilai Kapasitas Fagositosis Sel Makrofag (M.musculus) dengan Perlakuan Senyawa SA 2014 dan Doxorubicin

\begin{tabular}{|c|c|c|}
\hline $\begin{array}{c}\text { Konsentrasi } \\
(\mu \mathrm{g} / \mathrm{mL})\end{array}$ & $\begin{array}{c}\text { Kapasitas } \\
\text { Fagositosis } \\
\text { Perlakuan SA 2014 } \\
\end{array}$ & $\begin{array}{c}\text { Kapasitas Fagositosis } \\
\text { Perlakuan } \\
\text { Doxorubicin } \\
\end{array}$ \\
\hline Kontrol & $19,816 \pm 0,480^{\mathrm{b}}$ & $19,816 \pm 0,479^{\mathrm{b}}$ \\
\hline 1,25 & $18,973 \pm 0,929^{b}$ & $15,701 \pm 2,002^{\mathrm{ab}}$ \\
\hline 2,5 & $40,869 \pm 1,903^{d}$ & $17,868 \pm 1,884^{\mathrm{ab}}$ \\
\hline 5 & $31,690 \pm 1,863^{c}$ & $21,159 \pm 2,676^{b}$ \\
\hline 10 & $9,666 \pm 1,217^{\mathrm{a}}$ & $6,533 \pm 0,538^{a}$ \\
\hline
\end{tabular}

Uji ANOVA nilai kapasitas fagositosis sel makrofag dengan perlakuan SA 2014 maupun perlakuan doxorubicin menunjukkan nilai yang signifikan (Lampiran 1 dan 2). Analisis statistika dilanjutkan dengan uji Tukey. Hasil uji Tukey (Lampiran 3 dan 4) menunjukkan bahwa konsentrasi senyawa SA 2014 yang optimal dalam meningkatkan kapasitas fagositosis sel makrofag adalah 2,5 $\mu \mathrm{g} / \mathrm{mL}$, sedangkan konsentrasi doxorubicin yang mampu meningkatkan kapasitas fagositosis adalah $5 \mu \mathrm{g} / \mathrm{mL}$.

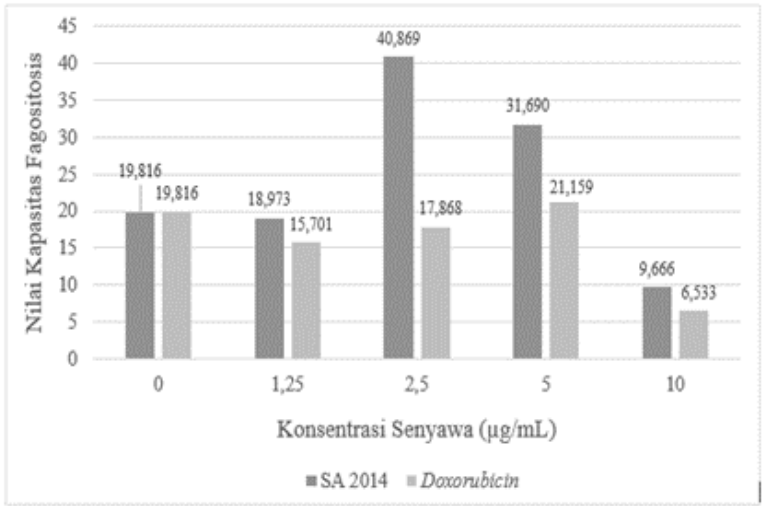

Gambar 2. Perbandingan Kapasitas Fagositosis Sel Makrofag Kontrol, Perlakuan SA 2014 dan Perlakuan Doxorubicin

Data pada Tabel 1. dan Gambar 2. menunjukkan bahwa sel makrofag dengan perlakuan SA 2014 tidak stabil dalam mempengaruhi nilai kapasitas fagositosis. Terjadi penurunan 
nilai kapasitas fagositosis pada konsentrasi $1,25 \mu \mathrm{g} / \mathrm{mL}$ sebesar 0,834 , namun pada konsentrasi $2,5 \mu \mathrm{g} / \mathrm{mL}$ dan 5 $\mu \mathrm{g} / \mathrm{mL}$ mengalami peningkatan secara berturut-turut sebesar 21,053 (2 kali lebih besar dibanding kontrol) dan 11,874. Selanjutnya pada konsentrasi $10 \mu \mathrm{g} / \mathrm{mL}$ mengalami penurunan kembali sebesar 10,150. Secara umum, perlakuan senyawa SA 2014 mampu meningkatkan kapasitas fagositosis karena 2 dari 4 variasi konsentrasi yang diberikan dapat menghasilkan nilai kapasitas fagositosis yang lebih besar dibanding perlakuan kontrol. Peningkatan kapasitas fagositosis yang terjadi pada kelompok perlakuan senyawa SA 2014 diduga disebabkan oleh adanya pengaruh penambahan senyawa alkaloid SA 2014 ke dalam kultur sel makrofag. Mekanisme kerja senyawa alkaloid SA 2014 sebagai imunomostimulant diduga dengan meningkatkan produksi IL-2 (interleukin 2) dan proliferasi limfosit dalam kultur [21]. Senyawa SA 2014 memiliki massa molekul yang besar yaitu $191.23 \mathrm{~g} / \mathrm{mol}$ [8]. Oleh karena itu untuk dapat masuk ke dalam sel limfosit, senyawa SA 2014 harus melalui proses transport aktif sekunder [1].

Senyawa SA 2014 yang telah masuk ke dalam sitoplasma sel limfosit menyebabkan sel tersebut teraktivasi. Sel limfosit yang teraktivasi akan mengaktifkan sitokin seperti interleukin-2 (IL-2) dan interferon- $\gamma$ (IFN- $\gamma)$. Sitokin tersebut akan mengaktifkan makrofag untuk memberikan respon terhadap antigen yang ada dalam tubuh [21]. Penambahan senyawa alkaloid SA 2014 akan meningkatkan aktivitas sel limfosit pada kultur, secara tidak langsung hal tersebut menyebabkan semakin banyak sel makrofag yang teraktivasi dan melakukan fagositosis latex beads sehingga didapatkan nilai kapasitas fagositosis yang cenderung lebih besar dibanding kontrol.

Penurunan nilai kapasitas fagositosis yang terjadi pada kelompok perlakuan senyawa SA 2014 diduga disebabkan oleh sifat senyawa SA 2014 yang sitotoksik. Sifat sitotositas yang dimiliki senyawa SA 2014 dapat menekan kerja imun (imunosupresif). Senyawa yang bersifat sitotoksik seperti alkaloid dapat menghambat proliferasi sel imun, produksi limfokin sel $\mathrm{T}$ serta mempengaruhi sistim fagosit melalui penekanan sistim myelopoiesis yang akan menurunkan pembentukan oksidan untuk membunuh antigen [22].

Sel makrofag dengan perlakuan doxorubicin memberikan hasil nilai kapasitas fagositosis yang lebih kecil dibanding kontrol pada 3 dari 4 variasi konsentrasi yang diberikan (Tabel 1 dan Gambar 2). Konsentrasi yang paling optimal adalah $5 \mu \mathrm{g} / \mathrm{mL}$ dengan peningkatan kapasitas fagositosis sebesar 1,343. Nilai kapasitas fagositosis yang rendah tersebut dapat disebabkan oleh doxorubicin yang berpengaruh pada sel-sel yang mengalami pembelahan sel secara cepat seperti sumsum tulang [23]. Di antara sel sumsum tulang belakang, prekusor hemopoetik merupakan sel yang paling sensitif terhadap sitotoksisitas dari doxorubicin [24]. Oleh karena itu, pada penggunaan doxorubicin banyak dijumpai leucopenia (jumlah sel darah putih yang terlalu rendah) serta penurunan interleukin-2 (IL2) dan produksi interferon- $\gamma$ (IFN- $\gamma$ ) yang merupakan komponen penting dalam sistem imun. Hal ini dapat menurunkan jumlah sel Natural Killer (NK), proliferasi limfosit serta rasio limfosit $\mathrm{T} \mathrm{CD}^{+} / \mathrm{CD}^{+}$yang juga menurunkan jumlah makrofag aktif dalam sistem imun [25].

\section{G. Indeks Fagositosis Sel Makrofag Mencit (M. musculus)} dengan Perlakuan Senyawa SA 2014 dan Doxorubicin

Data yang didapatkan melalui pengamatan mikroskop juga digunakan dalam perhitungan indeks fagositosis untuk mengetahui kemampuan masing-masing sel makrofag dalam memfagosit latex beads (Tabel 2 dan Gambar 3). Indeks fagositosis adalah perbandingan antara jumlah latex beads yang terfagosit dan jumlah makrofag yang aktif memfagositosis [20].

Tabel 2.

Nilai Indeks Fagositosis Sel Makrofag (M. musculus) dengan Perlakuan Senyawa SA 2014 dan Doxorubicin

\begin{tabular}{ccc}
\hline $\begin{array}{c}\text { Konsentrasi } \\
(\mu \mathrm{g} / \mathrm{mL})\end{array}$ & $\begin{array}{c}\text { Indeks Fagositosis } \\
\text { Perlakuan SA 2014 }\end{array}$ & $\begin{array}{c}\text { Indeks Fagositosis } \\
\text { Perlakuan Doxorubicin }\end{array}$ \\
\hline Kontrol & $1,611 \pm 0,212^{\mathrm{a}}$ & $\mathbf{1 , 6 1 1} \pm \mathbf{0 , 2 1 2 ^ { \mathrm { a } }}$ \\
1,25 & $1,506 \pm 0,231^{\mathrm{a}}$ & $1,333 \pm 0,059^{\mathrm{a}}$ \\
2,5 & $\mathbf{3 , 0 8 5} \pm \mathbf{0 , 6 1 1 ^ { \mathbf { b } }}$ & $1,131 \pm 0,051^{\mathrm{a}}$ \\
5 & $2,300 \pm 0,290^{\mathrm{ab}}$ & $1,205 \pm 0,064^{\mathrm{a}}$ \\
10 & $2,424 \pm 0,196^{\mathrm{ab}}$ & $1,194 \pm 0,009^{\mathrm{a}}$ \\
\hline \hline
\end{tabular}

Keterangan : Superskrip yang berbeda pada kolom yang sama menunjukkan perbedaan signifikan $(\mathrm{P}<0,05)$

Uji ANOVA nilai indeks fagositosis sel makrofag dengan perlakuan SA 2014 nilai yang signifikan, namun tidak signifikan pada perlakuan doxorubicin (Lampiran 5 dan 6). Analisis statistika dilanjutkan dengan uji Tukey. Hasil uji Tukey (Lampiran 7 dan 8) menunjukkan bahwa konsentrasi senyawa SA 2014 yang paling optimal dalam meningkatkan indeks fagositosis sel makrofag adalah 2,5 $\mu \mathrm{g} / \mathrm{mL}$. Sedangkan perlakuan doxorubicin tidak mampu meningkatkan nilai indeks fagositosis pada semua konsentrasi.

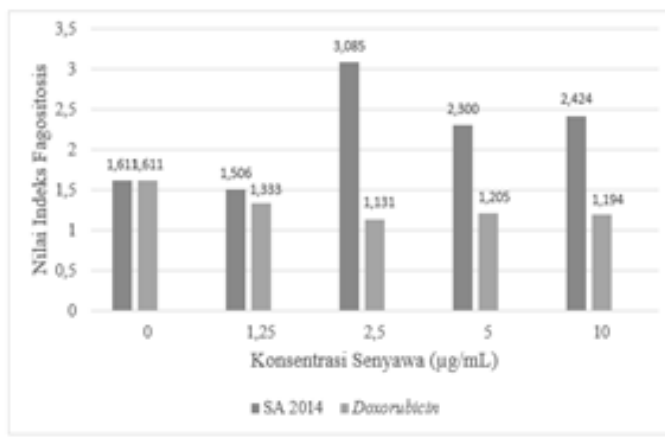

Gambar 3. Perbandingan Indeks Fagositosis Sel Makrofag Kontrol, Perlakuan SA 2014 dan Perlakuan Doxorubicin

Data pada Tabel 2. dan Gambar 3. menunjukkan bahwa sel makrofag yang diberi perlakuan senyawa SA 2014 pada semua konsentrasi kecuali konsentrasi $1,25 \mu \mathrm{g} / \mathrm{mL}$ memiliki nilai indeks fagositosis yang lebih tinggi dibanding kontrol. Konsentrasi senyawa SA 2014 yang paling optimal dalam meningkatkan nilai indeks fagositosis adalah konsentrasi 2,5 $\mu \mathrm{g} / \mathrm{mL}$ dengan meningkatkan indeks fagositosis 2 kali lebih besar dibadingkan kontrol. Peningkatan indeks fagositosis ini diduga disebabkan oleh semakin banyaknya sitokin yang dihasilkan oleh limfosit akibat perlakuan senyawa SA 2014. 
Sitokin-sitokin tersebut membuat makrofag semakin aktif dengan reseptor yang sensitif terhadap antigen. Dalam penelitian ini latex beads merupakan substansi yang berperan sebagai antigen. Latex beads dapat dianggap sebagai antigen karena dalam beberapa kasus substansi tersebut dapat memicu aktifnya sistem imun tubuh dengan respon berupa alergi [26].

Latex beads yang dianggap sebagai antigen dapat menginduksi makrofag untuk proses fagositosis. Proses fagositosis latex beads oleh sel makrofag diawali dengan menempelnya substansi tersebut pada reseptor di permukaan sel makrofag yang disebut Toll-like Receptor (TLR). TLR merupakan transmembran reseptor yang dapat mengenali Pathogen-Associated Molecular Patterns (PAMPs) (molekul spesifik patogen seperti lipoprotein, asam nukleat atau polystyrene beads). Pada TLR terdapat banyak jenis reseptor, namun yang merespon antigen latex beads adalah Macrophage Receptor with Collagenouse Structure (MARCO) [27]. Reseptor MARCO berperan berperan untuk mengenali partikel yang non-opsonisasi seperti silika, besi oksida, karbon arang dan polystyrene beads [28]. Penempelan latex beads dengan reseptor makrofag menginduksi pseudopodia untuk mengelilingi partikel tersebut, sehingga terbentuk fagosom. Pada fagosom terdapat NADPH oxidase yang berperan dalam menghasilkan oksidan anion superoksida $\left(\mathrm{O}_{2}^{-}\right)$hipoklorit $\left(\mathrm{OCl}^{-}\right)$dan hidrogen peroksida $\left(\mathrm{H}_{2} \mathrm{O}_{2}\right)$ yang bersifat toksik [29]. Fagosom menyatu dengan lisosom yang mensekresikan lisozim dan V-ATPase. Lisozim berfungsi dalam proses hidrolisis antigen, sedangkan V-ATPase berperan dalam menurunkan $\mathrm{pH}$ dengan melepaskan ion-ion $\mathrm{H}^{+}$. Akibat serangkaian proses tersebut antigen terfragmentasi sehingga terbentuk residual body [30]. Penurunan nilai indeks fagositosis sel makrofag dengan perlakuan SA 2014 diduga disebabkan oleh sifat sitotoksisitas yang dimiliki senyawa tersebut seperti yang dijelaskan pada sub-bab kapasitas fagositosis.

Sel makrofag dengan perlakuan doxorubicin pada semua konsentrasi tidak dapat meningkatkan indeks fagositosis sel makrofag. Hal tersebut dapat dilihat pada Gambar 3. dimana nilai indeks fagositosis sel makrofag perlakuan doxorubicin lebih rendah dibanding kontrol pada semua konsentrasi. Hal ini dapat terjadi karena doxorubicin memacu apoptosis melalui peningkatan ekspresi Bax. Bax berperan dalam menginduksi apoptosis melalui mitokondria [31]. Apoptosis yang terjadi menyebabkan kemampuan fagositosis sel makrofag. Salah satu karakteristik proses apoptosis yang terjadi pada kelompok perlakuan doxorubicin adalah kondensasi sitoplasma. Hal tersebut menyebabkan metabolisme sel makrofag terganggu sehingga tidak dapat membentuk pseudopodia dan tidak dapat mengenali antigen [19]. Oleh karena itu kemampuan fagositosis sel makrofag kelompok perlakuan doxorubicin pada semua variasi konsentrasi lebih rendah dibanding kontrol.

\section{KESIMPULAN}

Berdasarkan penelitian yang dilakukan dapat disimpulkan bahwa perlakuan senyawa SA 2014 mampu meningkatkan aktivitas fagostosis pada konsentrasi $2,5 \mu \mathrm{g} / \mathrm{mL}$ dengan kapasitas fagositosis serta indeks fagositosis 2 kali lebih besar dibanding kontrol. Sedangkan perlakuan doxorubicin dapat meningkatkan kapasitas fagositosis pada konsentrasi 5 $\mu \mathrm{g} / \mathrm{mL}$ 1,06 kali lebih besar dibanding kontrol namun tidak dapat meningkatkan indeks fagositosis.

\section{LAMPIRAN}

Lampiran 1.

Tabel 3.

Tabel Hasil Uji ANOVA Kapasitas Fagositosis Sel Makrofag dengan Perlakuan SA 2014

\begin{tabular}{|c|c|c|c|c|c|}
\hline & $\begin{array}{l}\text { Sum of } \\
\text { Squares }\end{array}$ & $\mathrm{df}$ & $\begin{array}{c}\text { Mean } \\
\text { Square }\end{array}$ & $\mathrm{F}$ & Sig. \\
\hline Between Groups & 1183.482 & 4 & 295.870 & 82.716 & .000 \\
\hline Within Groups & 17.885 & 5 & 3.577 & & \\
\hline Total & 1201.366 & 9 & & & \\
\hline
\end{tabular}

Lampiran 2.

Tabel 4.

Tabel Hasil Uji ANOVA Kapasitas Fagositosis Sel Makrofag dengan Perlakuan Doxorubicin

\begin{tabular}{lccccc}
\hline \hline & $\begin{array}{c}\text { Sum of } \\
\text { Squares }\end{array}$ & df & $\begin{array}{c}\text { Mean } \\
\text { Square }\end{array}$ & F & Sig. \\
\hline Between Groups & 199.678 & 4 & 49.919 & 9.819 & .014 \\
Within Groups & 25.419 & 5 & 5.084 & & \\
Total & 225.097 & 9 & & & \\
\hline \hline
\end{tabular}

Lampiran 3.

Tabel 5

Hasil Uji Tukey Kapasitas Fagositosis Sel Makrofag dengan Perlakuan SA 2014

\begin{tabular}{llll}
\hline \hline \multirow{2}{*}{ Konsentrasi } & \multicolumn{2}{l}{ Subset for alpha $=0.05$} \\
\cline { 3 - 4 } & & 1 & \multicolumn{2}{c}{2} \\
\hline 10.00 & 2 & 9.03250 & \\
1.25 & 2 & 15.70150 & 15.70150 \\
2.50 & 2 & 17.86750 & 17.86750 \\
.00 & 2 & 19.81600 \\
5.00 & 2 & 22.10250 \\
Sig. & \multicolumn{2}{c}{.055} & .160 \\
\hline \hline
\end{tabular}

Lampiran 4.

Tabel 6.

Hasil Uji Tukey Kapasitas Fagositosis Sel Makrofag dengan Perlakuan Doxorubicin

\begin{tabular}{lccccc}
\hline \hline & $\begin{array}{c}\text { Sum of } \\
\text { Squares }\end{array}$ & df & $\begin{array}{c}\text { Mean } \\
\text { Square }\end{array}$ & F & Sig. \\
\hline Between Groups & 3.859 & 4 & .965 & 8.708 & .018 \\
Within Groups & .554 & 5 & .111 & & \\
Total & 4.413 & 9 & & & \\
\hline \hline
\end{tabular}

Lampiran 5.

Tabel 7.

Hasil Uji ANOVA Indeks Fagositosis Sel Makrofag dengan Perlakuan SA 2014

\begin{tabular}{lcccc}
\hline \hline & Sum of Squares & df & Mean Square & F \\
\hline Between Groups & .332 & 4 & .083 & 1.292 \\
Within Groups & .321 & 5 & .064 & \\
Total & .653 & 9 & & \\
\hline \hline
\end{tabular}


Lampiran 6.

Tabel 8.

Hasil Uji ANOVA Indeks Fagositosis Sel Makrofag dengan Perlakuan Doxorubicin

Subset for alpha $=0.05$

\begin{tabular}{cccc} 
KONSENTRASI N & 1 & 2 \\
\cline { 3 - 4 } .00 & 2 & 1.41300 & \\
1.25 & 2 & 1.50600 & \\
5.00 & 2 & 2.29950 & 2.29950 \\
10.00 & 2 & 2.42450 & 2.42450 \\
2.50 & 2 & & 3.08500 \\
Sig. & & .130 & .263 \\
\hline \hline
\end{tabular}

Lampiran 7.

Tabel 9.

Hasil Uji Tukey Indeks Fagositosis Sel Makrofag dengan Perlakuan SA 2014

Subset for alpha $=0.05$

KONSENTRASI N

1

\begin{tabular}{ccc}
\hline 10.00 & 2 & 1.19400 \\
2.50 & 2 & 1.23050 \\
1.25 & 2 & 1.33350 \\
.00 & 2 & 1.61150 \\
5.00 & 2 & 1.61400 \\
Sig. & & .526 \\
\hline
\end{tabular}

\section{DAFTAR PUSTAKA}

[1] E. . Martini, F.H., Nath, J.D. and Bartholomew, Fundamentals of Aanatomy and Physiology Ninth Edition. United States of America: Pearson Education, Inc, 2012.

[2] L. Anggorowati, "Faktor Risiko Kanker Payudara Wanita," $J$. KEMAS, vol. 8, no. 2, pp. 102-108, 2013.

[3] S. . Mader, Understanding Human Anatomy and Physiology. USA: Mc. Graw-Hill, 2004.

[4] Y. Nurhayati, S. dan Lusiyanti, "Apoptosis dan Respon Biologik Sel sebagai Faktor Prognosa Radioterapi Kanker," J. IPTEK Ilm. Pop., vol. 7, no. 3, pp. 57-66, 2006.

[5] K. . Stephens, F.O. and Aigner, "Basics of Oncology," Springer, 2009.

[6] S. dan K. Tyastuti, E.M., "Efek Imunostimulator Propolis terhadap Proliferasi Limfosit $\mathrm{T}$ dan Viabilitas Sel Tumor Mammae Mencit secara in Vitro," J. Bioteknol., vol. 3, no. 1, pp. $1-7,2006$.

[7] A. Nugrahaningsih dan Yuniastuti, "Identifikasi Apoptosis dengan Metode Tunel Pasca Pemberian Ekstrak Sambiloto dan Pengaruhnya terhadap Volume Tumor," J. Sain dan Teknol., vol. 12, no. 2, pp. 139-146, 2014.

[8] S. Nurhayati, A.P.D., Pratiwi, S., Wahyuono, S., Istriyati., Abdillah, "Isolation and Identification of Alkaloid Compound of Marine Sponge Cinachyrella sp. (Family Tetillidae)," J. Adv. Bot. Zool., 2014

[9] Fatmah, "Respons Imunitas yang Rendah pada Tubuh Manusia Usia Lanjut," Makara, Kesehat., vol. 10, no. 1, pp. 47-53, 2006.

[10] A. Hartini, Y.S., Wahyuono, S., Widyarini, S. dan Yuswanto,
"Uji Aktivitas Fagositosis Makrofag Fraksi-fraksi dari Ekstrak Metanol Daun Sirih Merah (Piper crocatumRuiz \& Pav.) secara In Vitro," J. Ilmu Kefarmasian Indones., vol. 11, no. 2, pp. 108$115,2013$.

[11] L. Pecorino, Molecular Biology of Cancer Mechanisms, Targets, and Therapeutics Third Edition. United Kingdom: Oxford University Press, 2012.

[12] A. Puspitasari, "Optimasi Ekstraksi dan Penelusuran Fraksi Aktif Herba Sambiloto (Andrographis paniculata nees.) dan Patikan Kebo (Euphorbia hirta 1.): Studi in vitro Efek Fagositosis Makrofag," Universitas Gadjah Mada.

[13] J. R. . Jensch-Junior, B.E., Pressinotil, N., Borges, J.C.S. and Cunha da Silva, "Characterization of Macrophage Phagocytosis of the Tropical Fish Prochilodus scrofa (Steindachner, 1881)," J. Aquac., vol. 251, pp. 509-515, 2006

[14] M. . Rahayu, "Aktivitas Fagositosis Makrofag dari Fraksi NHeksan Herba Sambiloto (Andrographis Paniculata, (Burm.F) Nees) terhadap Mencit yang Diinduksi Vaksin Hepatitis B," $J$. Pharm., vol. 11, no. 2, pp. 181-199, 2014.

[15] R. . Susanti, R., Yuniastuti, A. dan Iswari, "Aktivitas Reactive Oxygen Species Makrofag Akibat Stimulasi gel Lidah Buaya pada Infeksi Salmonella typhimurium," J. MIPA, vol. 35, no. 1, pp. 1-10, 2012.

[16] J. . Atlas, R.M. and Snyder, Handbook of Media for Clinical Microbiology Second Edition. CRC Press, 2006.

[17] E. Widjajanto, "Peranan Makrofag pada Proliferasi, Diferensiasi dan Apoptosis pada Proses Hematopoisis (Penelitian pada Limpa Janin Tikus dan Aspirat Sumsum Tulang Manusia)," J. Kedokt. Brawijaya, vol. 21, no. 1, pp. 29-36, 2005.

[18] I. Mustafiah, S.E., Fatmawati, S. dan Yusuf, "Indeks Daya Fagosit Makrofag Peritoneum setelah Pemberian Propolis pada Mencit (Mus musculus)," J. Sains Med., vol. 3, no. 2, pp. 121128,2011

[19] J. J. A. Cohen, "Journal of Immunology Today," vol. 14, pp. 126-130, 1993.

[20] D. Aldi, Y., Novelin, F. dan Handayani, "Aktivitas Beberapa Subfraksi Herba Meniran (Phyllanthusniruri Linn.) terhadap Aktivitas dan Kapasitas Fagositosis Makrofag," J. Sci., vol. 5, no. 2, pp. 92-96.

[21] H. . Sholikhah, A.R. dan Rahayuninsih, "Pengaruh Ekstrak Lompong (Colocasia esculenta L. Schoot) 30 Menit Pengukusan Terhadap Aktivitas Fagositosis dan Kadar NO (NITRIT OKSIDA) Mencit Balb/C Sebelum dan Sesudah Terinfeksi Listeria Monocytogenes," J. Nutr. Coll., vol. 4, no. 2, pp. $463-$ 468,2015

[22] S. Andayani, "Aktivitas Fagosit Makrofag dan Histopatologi Ginjal Ikan Kerapu Macan setelah Diberi Immunostimulan Alkaloid Ubur-Ubur (Bougainvillia sp) dan Diinfeksi Vibrio harveyi," J. Berk. Penel. Hayati Ed. Khusus, vol. 6B, pp. 13-17, 2011.

[23] M. . Philip, A.H., Garai, A.S. and Valenzuela, "Reduction of Doxorubicin (Adriamycin) Bone Marrow Toxixity," $J$ Pharmaeutical Sci., vol. 64, no. 9, pp. 1574-1576, 2006.

[24] A. Uspenskaya, Y.A., Mikhutkina, S.V., Taksanova, E. Popova, N.N., Olovyannikova, R.Y. and Salmina, "Induction of Apoptosis in Bone Marrow Cells in Mediated via Purienic Receptors," Byulleten "Eskperimental"noi Biol. I Medistiny, vol. 8, no. 138 , pp. 135-138, 2004

[25] T. Zhang, X., Li, W., Wu, Y.J.G. and Ming, "Amelioration of Doxorubicin-Induced Myocardial Oxydative Stress and Immunosupression by Grape Seed Proanthocyanidins in Tumourbearing Mice," J Pharm Pharmacol, vol. 57, no. 8, pp. 10431051, 2005.

[26] W. Andriyanti, W., Darsono and Faisal, "Study of Natural Rubber Latex Method Free Nitromines and Protein Allergens," $J$. ISSN 0216-3128, pp. 161-169, 2010.

[27] S. M. and J. C. S. Cervantez, J.L., Hawley, K.L., Benjamin, S.J., Winerman, B., Luu, "Phagosomal TLR Signaling u on Borrelia burgdorferi Infection," J. Front. Cell. Infect. Microbiol., vol. 4 no. 55, pp. 1-12, 2014.

[28] S. Hirano, S. and Kanno, "Macrophage Receptor with Collagenous Structure (MARCO) Is Processed by either Macropinocytosis or Endocytosis-Autophagy Pathway," J. Plos One, vol. 10, pp. 1-16, 2015.

[29] and C. A. Dugenci SK, Arda N, "Some Medicinal Plants as Immunostimulant for Fish," J. Ethnopharmacol., vol. 88, pp. 99106, 2003.

[30] S. Gordon, "Phagocytosis: An Immunobiologic Process," $J$. Immun., vol. 463-475, 2016

[31] W. Yong, Z., Jiang, L., Zong, L., Wen-liang, W. and Zhong, 
"Bax Overex- pression Enhances Apoptosis Induced by Adriamycin in HCC-9204 Cells," Chinese J. Cancer Res., vol. 16, no. 3, pp. 157-161, 2004. 